Article

\title{
Housing in the Neoliberal City: Large Urban Developments and the Role of Architecture
}

\author{
Merryan Majerowitz * and Yael Allweil \\ Faculty of Architecture and Town Planning, Technion IIT, 3200003 Haifa, Israel; E-Mails: merryan@campus.technion.ac.il \\ (M.M.), aryael@technion.ac.il (Y.A.) \\ * Corresponding author
}

Submitted: 24 June 2019 | Accepted: 23 September 2019 | Published: 21 November 2019

\begin{abstract}
Large urban developments (LUDs) have been driving contemporary neoliberal urban housing development worldwide, marked by scholarly and public discourses on the transition from housing as a basic civil right to housing as investment channel and financial good. Based on interviews, documentary films, architectural drawings and planning documents, this article examines the interrelations between architectural and entrepreneurial factors shaping LUDs in the contemporary neoliberal context. Analyzing several LUDs in Israel, Denmark and Spain, this article unpacks the paradox of neoliberal housing development-namely the unfulfilled free market promise of variety and multiple choice versus the reality of replicated, uniform dwelling units in repetitive residential buildings and identical neighborhoods characterizing residential landscapes worldwide. This article explores the corresponding relationship between design elements, design processes and entrepreneurial marketing decision-making. Our study reveals the cardinal role of architectural design in characterizing, financing, licensing and marketing LUDs, labeling them as unique-rather than uniform-developments compared with 'regular' neighborhoods.
\end{abstract}

\section{Keywords}

architectural design; housing development; large urban development; neoliberalism; urban housing

\section{Issue}

This article is part of the issue "Large Urban Developments and the Future of Cities" edited by Efrat Eizenberg (TechnionIsrael Institute of Technology, Israel).

(C) 2019 by the authors; licensee Cogitatio (Lisbon, Portugal). This article is licensed under a Creative Commons Attribution 4.0 International License (CC BY).

\section{Introduction}

A key contemporary venue for financial growth in late capitalism, large urban developments (LUDs) have come to dominate contemporary global urban processes (Harvey, 2010). This urban phenomenon has been largely framed through social and political consequences for the right to the city, as well as debates around urban planning-from planning policy to principles like community, walkability, and preservation of the social fabric.

This article expands the scholarship on LUDs by identifying a gap in the literature regarding the mechanisms producing these urban frameworks. While much scholarly attention is given to the economic, policy, and ur- ban politics, we point to the role of architectural design of LUDs as the missing link in understanding this important phenomenon. Our article focuses on four cases of new middle-class housing LUDs, all pioneers in architectural design: Herzliya Hills $(\mathrm{HH})$ by Braz Architects; the 8 House by the Bjarke Ingels Group (BIG); the VM House by BIG; and JDS and the MIRADOR by MVRDV and Blanca Lleó Associates. Located in large, unappealing tracts of land-flanked by highways, national infrastructures or the urban periphery-LUDs required a new development strategy that extends the simple neoliberal codification of housing as real estate commodity, which has dominated the development of housing in the past three decades. 
These cases unpack the paradox of neoliberal housing development and its unfulfilled free-market promise of variety and multiple choice: uniform dwelling units arranged in repetitive residential buildings and identical neighborhoods that characterize the landscape of residential neighborhoods across the world. Like many neoliberal housing developments, LUD planning processes led by entrepreneurial companies employ comprehensive planning teams composed of economists, marketing experts, and lawyers. Nonetheless, our study exposes the central role of architects in characterizing, financing, licensing, and marketing LUDs. Aimed at marking the LUD as a unique-rather than uniform-development, architects assume an unexpected leading role for the design and marketability of otherwise-unappealing developments, when compared with 'regular' neighborhoods.

\section{Methodology and Research Design}

This article limns the interrelations between architectural and entrepreneurial decision-making shaping LUDs in the contemporary late capitalist urban development. Research methods include classic methods of architectural inquiry such as analysis of planning documents, visual data, design decision making, and architectural attributes like views, movement, etc. In addition, we conducted interviews with designers, real estate agent and developers, and conducted content analysis of interviews with designers and documentary films of the LUDs studied. We conducted comparative analysis of the various sources, checking documents of the buildings themselves against statements by the architects and developers, and interviews with marketing personnel and dwellers, and documentary footage.

We study locales in which LUDs were developed by national and/or municipal housing ministries. The context for this article, therefore, is the transformation of large housing estate development from government to the neoliberal market. As we elaborate below, Israel, Denmark, and France have been celebrated examples of state-developed housing for the greatest number. The comparison we offer here aims to go beyond Israel, to discuss the neoliberal transformation in housing development in former 'benevolent state' locales.

Our choice of case studies focuses on LUDs where renowned architects were involved, from the early stages of development, in designing commercial mass housing as a product in the neoliberal context. This phenomenon is relatively new, as market housing in the past decades has rarely involved architects in leading roles in producing estates. The cases chosen are well known in the professional literature for pioneering housing LUD in their specific locales, and for employing high-profile architecture firms-BIG, MVRDV, and Braz. Architectural, ethnographic, economic and design decision making data of these cases is available, marking them appropriate for comparative research of an emerging global phenomenon.

\section{Conceptual Frameworks}

In order to identify categories for inquiry and comparative analysis of LUDs where the role of architecture has been significant for neoliberal development of large housing estates, we have examined three related fields of inquiry: (a) LUDs as global, neoliberal urban development; (b) housing from social project to LUD; and (c) the politics of the architectural envelope. Employing these fields of inquiry, we were able to carefully select case studies for comparative study, and eventually identify the three thematic categories for critical analysis discussed below.

\subsection{LUDs as Global, Neoliberal Urban Development}

David Harvey identifies LUDs as a key tool for capital extraction at periods of financial crisis in modernity. His research harkens back to the role of LUDs as a key mechanism for the expansion of capital to the Haussmanization of Paris, as the first case of capitalist expansion via the city (Harvey, 2003a). As global capitalism has exhausted its avenues for geographic expansion to new markets, it now directs most efforts to intensifying urban development via LUDs. The social consequences of LUDs for access and right to the city as well as for urban citizenship are grave, forcing the poor and working-class out of the city (Harvey, 2004, 2012; Lefebvre, 1991; Mitchell, 2003). Discussing contemporary Chinese new towns, for example, Harvey portrays the urban setting as the key contemporary outlet for meeting capital's constant need for growth (Harvey, 2003b, 2010).

The capitalist driving force behind LUDs has generally privileged capital extraction over urban planning and urban design principles, compromising the city and the wellbeing of urban citizens, as well as professional planning processes in many cities (Gualini \& Majoor, 2007; Salet, 2008). Diverging from well-accepted professional principles of urban form-like density, walkability, human scale, and community-LUDs are producing a new form of urbanity and urban life (Amsterdam, Delft, \& Eburon, 2017). Research regarding the significance of LUDs on urban form points to a sea of change in conceptions of planning. The dominance of LUDs in contemporary urban development places capital as the driving force in the planning of cities worldwide, while reflecting deep changes in policy making at state and urban levels favoring a neo-liberal approach (Swyngedouw, Moulaert, \& Rodriguez, 2002). This change is associated with the privatization of space-particularly the privatization of the housing market-dominated by the real estate sector that replaced social housing with for-profit urban politics (Novy, Redak, Jäger, \& Hamedinger, 2001; Swenarton, Avermaete, \& Van Den Heuvel, 2014).

\subsection{Housing: From Social Project to LUD}

The processes of dispossession and disenfranchisement revolving around LUDs are intensified by housing devel- 
opments. Housing LUDs-compared to public or commercial complexes-decisively catalyze the neoliberalization of the city (Brenner, Marcuse, \& Mayer, 2011; Marcuse \& Madden, 2016).

Since modernity, housing for the 'greatest number' has posed great planning and design challenges. Urban housing for the masses requires developing large-scale design (Eleb, 2000). Mass housing emerged as a social, spatial, and political challenge following the Industrial Revolution, and stood out in its impact on society in early capitalism (Engels, 1872/1993). Since the latenineteenth century, housing design and production has reshaped the urban fabric, social processes in the city and nation, and the integration of workers into the city and urban politics. Architectural design has been central in search for design principles shaping large housing developments since the articulation of mass housing projects in the 1920s (Bauer, 1934; Le Corbusier, 2008). Post-war rebuilding projects by welfare states involved the creation of new towns and mass housing estates worldwide. These were, by definition, LUDs in terms of planning and architectural design, albeit produced by state rather than the market (Cupers, 2014; Swenarton et al, 2014; van den Heuvel \& Risselada, 2005).

The study cases reviewed, and others, are part of societies where social housing has dominated the housing stock in the post-WW2 period. These locales provide a fascinating context for studying transformations in housing LUDs, from state-produced housing for the 'greatest number' to market-based mass housing. Israeli nationbuilding has largely relied on housing as a key mechanism of sovereignty and statehood with large-scale development of new towns and mass immigrant housing nationwide (Allweil, 2017; Efrat, 2019). In France, social housing served as a tool for social and geopolitical reconstruction for modernizing and incorporating citizens (Cupers, 2014; Parvu, 2010). In the Netherlands, post-war ideology of an open society was explicitly constructed by means of designed explorations of social housing (van den Heuvel, 2015), while in Denmark and Sweden social housing has attempted unifying and equalizing goals towards social cohesion (Mattsson, 2015, Vestergaard \& Scanlon, 2014). In the United Kingdom significant contributions to architecture theory involved the design of radical housing estates (Boyer, 2017; Smithson, Smithson., van den Heuvel, Risselada, \& Colomina, 2004). In the early 1970s, state housing worldwide was gradually privatized. "The paradox in the story of the welfare state is that the moment when egalitarianism seemed to be finally realized...the system started to collapse due to the financial crisis," states van den Heuvel (2014, p. 149). Rather than initiating, planning, building, and marketing housing units, state and municipal housing bureaus limited themselves to coordinating market-based developments (Swenarton et al., 2014). Consequently, housing gradually turned from public good to consumer product and from civil right to investment channel. Housing discourse is dominated by entrepreneurs, brokers, and ap- praisers with architects largely marginalized from housing development processes (Mota \& Allweil, 2019).

\subsection{The Politics of the Envelope}

In his pioneering discussion of late capitalist architecture, Fredric Jameson (1991) identified the role of architecture in late-capitalist LUDs as the chief cultural agent of what we now term neoliberalism. For Jameson, architecture reflects shifts in patronage and financing involved in creating urban and architectural spaces, as well as the deep changes to the social and political role of the architect versus developers and clients (Jameson, 1991). The architecture of late capitalism is often discussed within the framework of a shift in architecture culture, defined by the failure to bridge responsibility to social needs like mass housing with artistic creation (Marcuse \& Madden, 2016; Martin, Moore, \& Schindler, 2015; McLeod, 1989; Self, 2014). In his The Architecture of Neoliberalism, Douglas Spencer (2016) analyses several architectural projects to assert that neoliberalism and the architecture compliant to its agenda have produced projects designed to serve as forms of capital extraction. Spenser's critique of the architecture of neoliberalism echoes the work of noted political economists Aalbers (2016) and Mazzucato (2018), who study the financialization of the housing market and the financial system's attempts to rethink the nature and mechanisms for extracting value.

Architecture theoretician Alejandro Zaera-Polo (2008) discusses 'the politics of the envelope,' pointing to the building's envelope as the most significant design element in the architecture of late capitalism. The 'populist' nature of neoliberal architecture revolves around designed envelopes: producing recognizable figuration, diagrammatic direct messages, and simplification of the buildings' elements for easier communication (ZaeraPolo, 2017). In housing LUDs, building-envelope design can transform regular multi-family buildings into residential environments with desirable form (Stoiljkovi \& Jovanovi, 2015). This is done by 'dressing' or 'enveloping' the development with the cultural agent of architecture. Yet how can we understand the 'dressing' or 'enveloping' of a development beyond theory? What are the actual practices and decision-making processes involved in reengaging architecture in large housing developments, and in relegating it to the envelope? What effect does the explicit role of 'dressing' and its separation from space planning and other aspects of the design process have on the quality of housing produced?

\section{Findings and Analysis}

While LUD development is well discussed in planning and political-geography literature-with attention to the consequences for city planning - the role of architectural design in realizing large neoliberal urban housing developments remains understudied. This article aims to address 
this gap by tracing the role of architecture in contemporary housing development by examining four housing LUDs developed in the last decade in Herzliya (Israel), Copenhagen, and Madrid.

We developed three analytical categories that cut across the design processes recurring in our four case studies, pointing to a corresponding relationship between design elements, design processes and entrepreneurial decision making: (a) value via architecture-desirability and image; (b) rearticulating urban form; and (c) the neoliberal estate. These analytical categories allow us to explore and compare design strategies employing architecture in the service of neoliberal development of housing estates as large urban segments. Shedding light on the significant role of architectural design in contemporary LUD creation, these analytical categories are informed by detailed data on the actual ways in which architecture works as a valueenhancing apparatus.

\subsection{Value via Architecture: Desirability and Image}

While housing for the masses have not tended to include investment in architectural design, in the past decade we can see a new phenomenon of market investment in housing LUD architecture from the early stages of development. Investing resources and involving architects in the process aims to produce and market housing as a desirable product, often in an attempt to overcome LUD drawbacks like remote location, lack of urban environment, or lesser-quality spatial characteristics like high density. Our case studies 8 House, VM House, Mirador and $\mathrm{HH}$, designed by BIG, MVRDV and Braz firms respectively, epitomize this new phenomenon and allow for comparative inquiry of its characteristics.

$\mathrm{HH}$, a new housing development of large middleclass housing, offering 600 apartments, is a gamechanging LUD in the Israeli context. Located on a large tract of land in an unappealing location between highways and national infrastructures, physically distant from the city center, $\mathrm{HH}$ is an isolated LUD whose development required a new strategy that extends neoliberal development processes which have dominated Israeli housing production for the past four decades.

Itai Cohen, the real estate agent charged with marketing $\mathrm{HH}$ discusses the marketing challenges revolving this project (I. Cohen, personal communication, May 14 , 2019). While in close proximity to several large employment and entertainment hubs and with convenient auto access to major national highways, HH's location amidst highways and railways produces extreme conditions of noise inferences and air pollution, as well as limited integration with Herzliya's desirable urban fabric (Figure 1). As a popular newspaper put it: "A residential neighborhood combined with high-density offices right on Highway 2, facing the busy industrial zone junction, blocked from all directions between busy roads and interchanges. Who would want to live in such a place?" (Handel, 2018).

The developers of $\mathrm{HH}$-Azorim Corporation-hired Kika Braz Architects in an attempt to deal with the site's desirability problem using design (K. Braz, personal com-

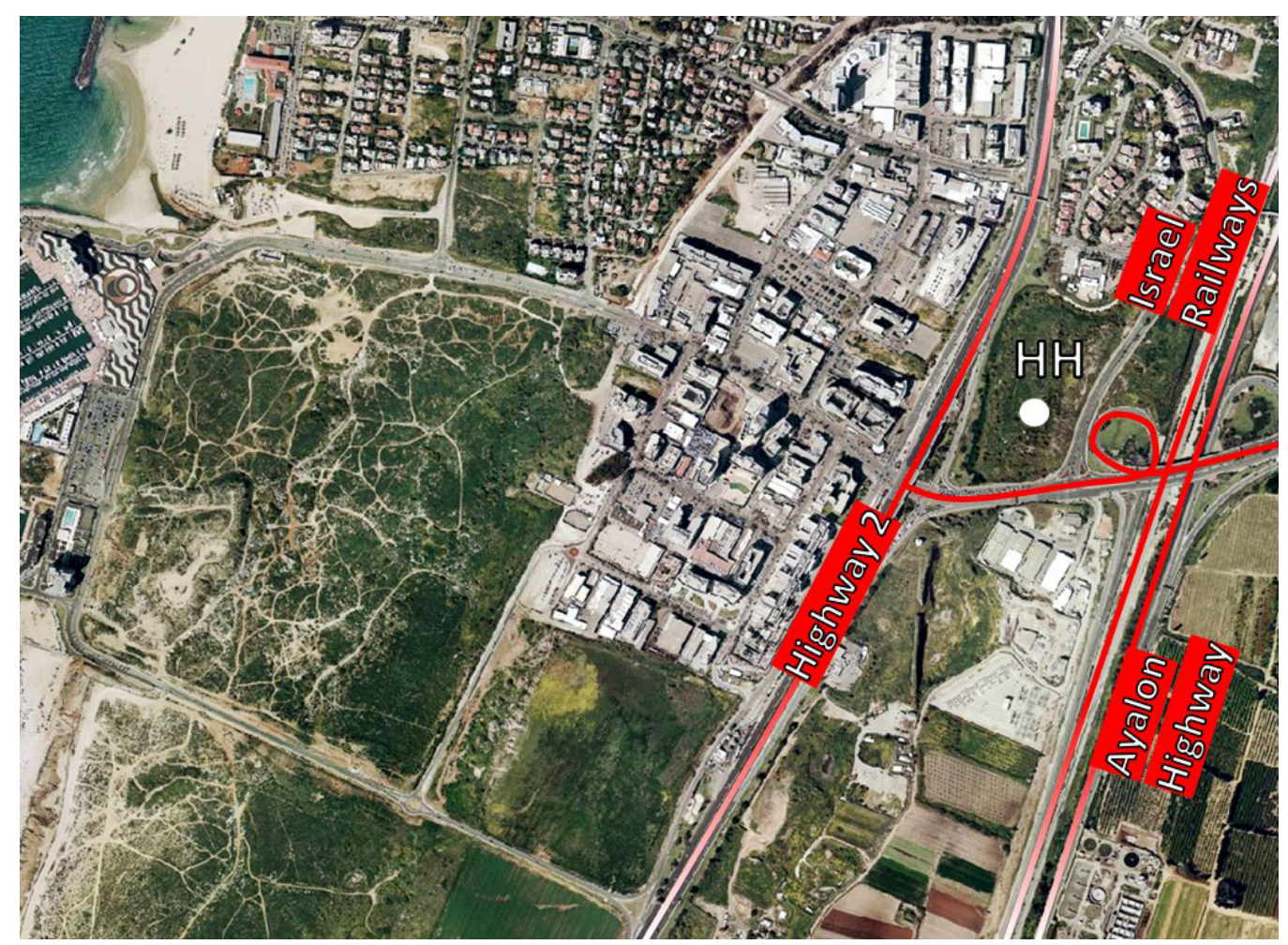

Figure 1. Aerial photograph of HH. Source: Adapted from K. Braz private collection. 
munication, December 18, 2018). According to Braz, marketing considerations played a leading role in the design process of $\mathrm{HH}$ as early as in the conceptual phase (K. Braz, personal communications, July 13, 2013; December 18, 2018). Her design approach to the constraints of the site proposed an urban landmark with iconic architectural image, in order to unify the 70-acre site and highlight its advantages as LUD. Facing the highways and rails "required a prominent visual effect to catch the eye at short exposure," Braz says. Her design involved a study of slowexposure photography of highway perspectives-long, continuous stripes of bright-red taillights over the dark landscape-which served as the catalyst for the long, red façades facing Highway 2 (Figure 2). Braz's architecture converses with Zaera-Polo's discussion of 'the politics of the envelope,' her design of the building's envelope a recognizable figuration that simplifies the building for easier consumption.

Cohen indicates that the appealing architecture of $\mathrm{HH}$ was significantly profitable, able to contribute to the project's profits compared with second-hand apartments in the adjacent neighborhood, which has similar advantages in terms of proximity and access to national transportation but is not trapped between roads. Cohen points to two aspects of his marketing strategy of the LUD that rely on values produced via architectural design: the self-sufficient character of the development, and the sense of community it offers (I. Cohen, personal communication, May 14, 2019).

Architect Dany Rozen, head architect of $\mathrm{HH}$, defines formal simplification as the organizing design principle providing "a clear logic of the form" (D. Rozen, personal communication, March 20, 2019). The Braz firm assigns a special designer devoted to envelope design, nicknamed 'the dresser.' This designer focuses on the envelopes of various projects in the firm, a task separated by Braz from the functional design of the building:

We developed a method we call 'the dress' [Braz explains] that strips the body of the building from its façade and allows designing the 'dress' separately from apartment plans. While 'the dresser' designs the elements and materiality of the façade, other architects can work on the programmatic and regulatory aspects of design. (K. Braz, personal communication, December 18, 2018)

The HH 'dress' is a structural element that, just like a dress on a human body, does not necessarily follow the body's outline. The 'dress' camouflages the building's form - the product of functional apartment outlines and regulatory requirements inscribed in building codes that determine opening directions and sizes, safety measures and economic considerations affecting floorplan areasproducing a complex needs-based structural outline for the floorplans far from the holistic design vision for the entire LUD. The 'dress' - clinging to the 'body' at times, loose elsewhere-forms a mediated space disguised due to the natural shadow the 'dress' casts on the body while the dark tiles cover the original recessed façade (Figure 3).

The 'dress' consists of two parts: the red ground floors that constitute a long overarching façade unifying the LUD, and the white skin springing from the fourth

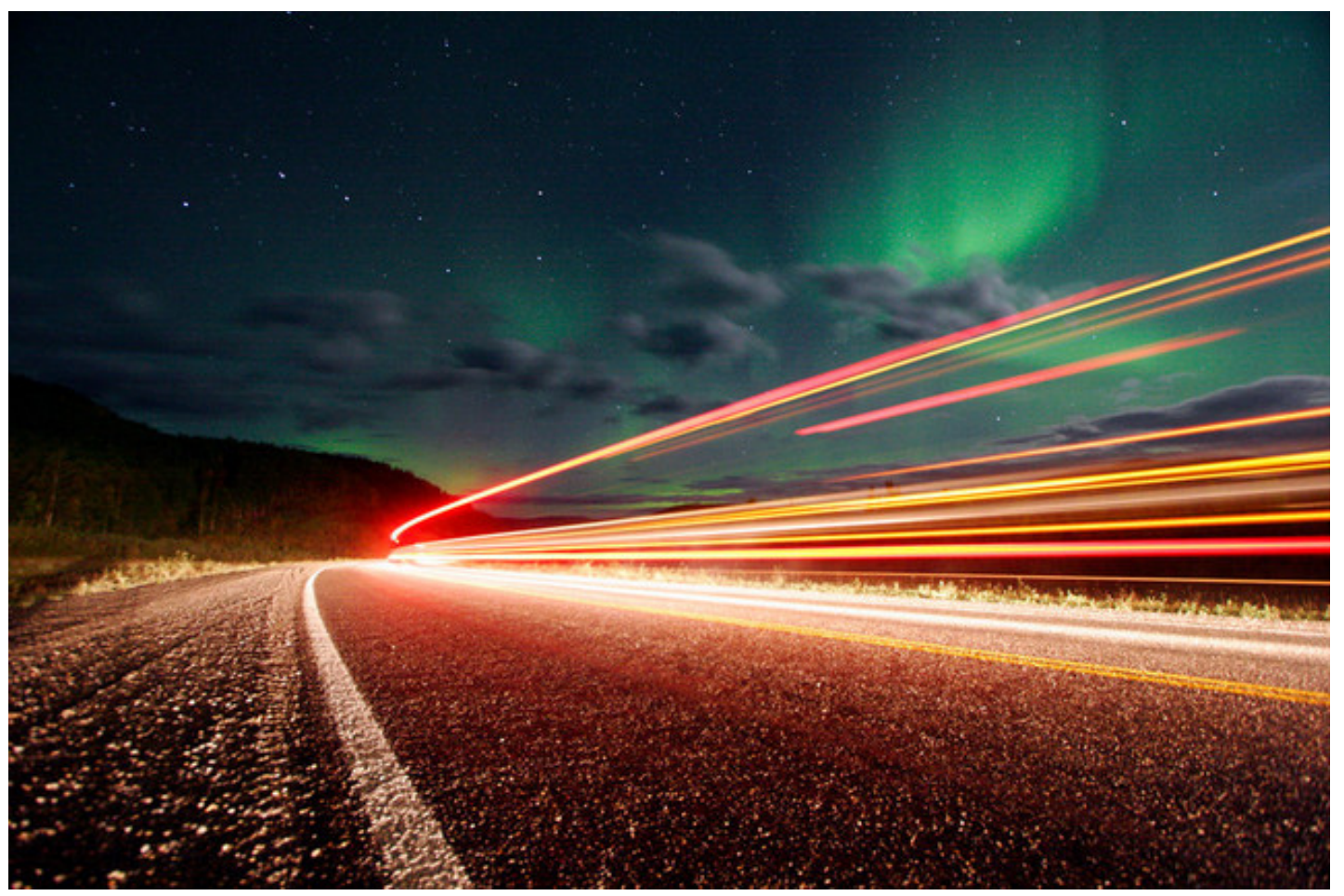

Figure 2. Braz's inspiration image. Slow-exposure photography of highway perspectives. Source: K. Braz private collection. 


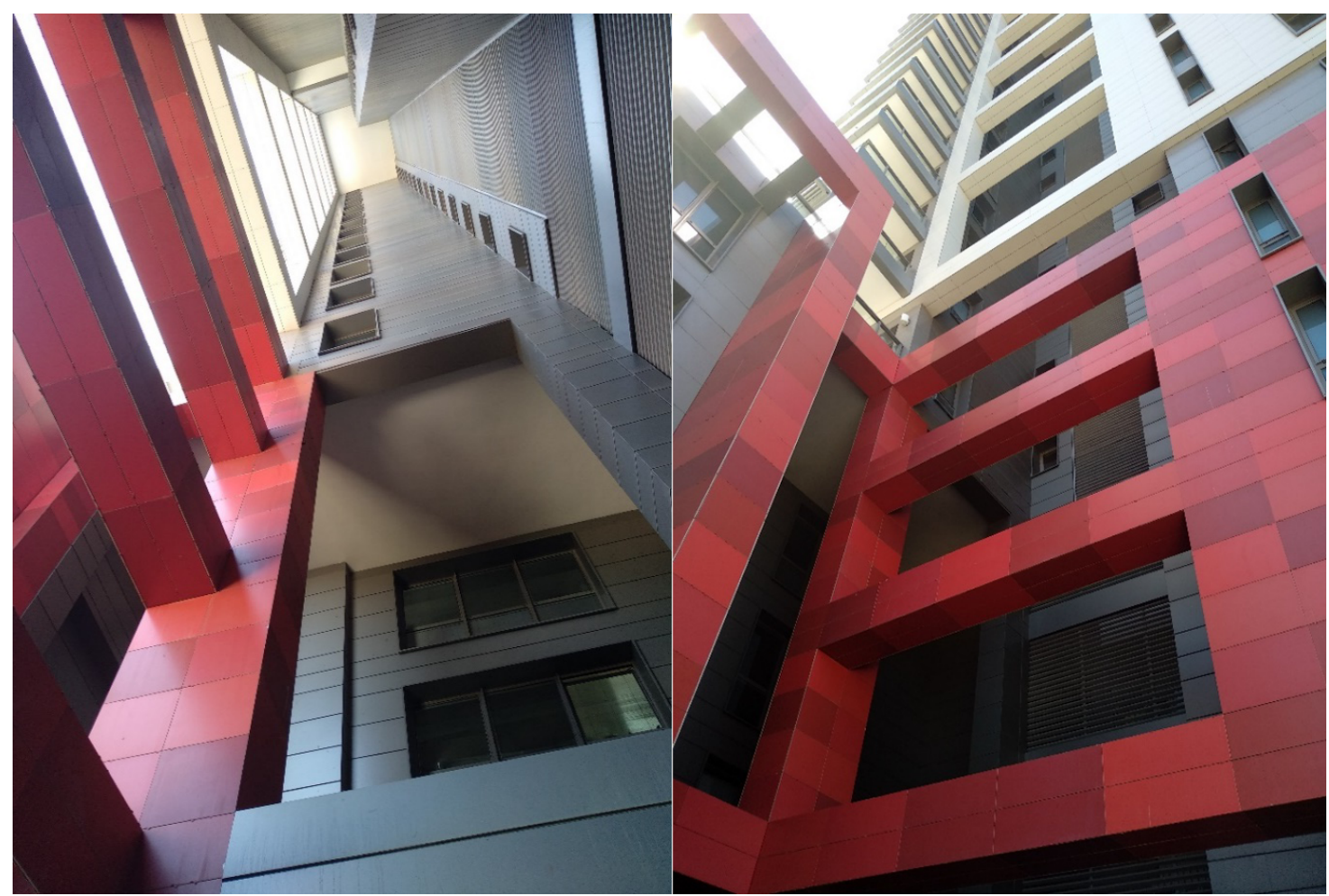

Figure 3. The 'dress' zoom-in. Source: Authors (2019).

floor up, covering the six residential towers (Figure 4). The red slab shields six smaller residential structures at the inner part of the site, labelled 'boutique buildings' (Figure 5). The unifying role of the 'dress' is most expressed where it is distanced from the structure, primarily along the west façade viewed from Highway 2 . Within $\mathrm{HH}$, the 'dress' can be seen clearly from the penthouse level; in Figure 6 we can see it as a stand-alone, removed from the roof and the functional façade. D. Rozen (personal communication, March 20, 2019) explains that the full effect of the 'dress,' as seen from afar, was produced by using granite tiles painted several hues of red, in a pattern carefully designed using a parametric system in grasshopper software, to optimize its three-dimensional effect (Figure 7). Braz architects then traveled to the tile manufacturer in Spain in order to select the precise hues, and the refraction and reflection requirements for these tiles. The tiles were assembled on site using an expansive dry cladding method for better durability, uncommon for dwellings in Israel.

Construction of the 'dress' element exceeded the cost of $\mathrm{HH}$ by a conservative estimate of $25 \%$ compared with Azorim Corporations' similar housing developments (G. Guedj, personal communication, June 4, 2019). Nonetheless, Azorim was willing to invest financial resources in the 'dress,' reflecting a sense that architectural design would result in profit and value production. Gal Guedj, a regional manager at Azorim, explains that it was a pioneering decision. It extended the budget, yet contributed to the unique image of $\mathrm{HH}$ with marketing results (G. Guedj, personal communication, June 4,
2019). HH is indeed among the first housing LUDs in Israel to assign architecture a leading role in design decisions over marketing and sales in order to stand out in a built environment composed largely of replicated residential towers (Brand \& Shalom, 2014).

'Dress-making' is a dominant mechanism of architectural design in contemporary housing LUDs, including award-winning 8 House development outside Copenhagen (Rosenberg, 2010). Located in Ørestad district, the new 'finger' of Copenhagen was at the beginning consider a controversial project as the island of Amager considered marginal and sleepy (Majoor, 2014). Ørestad's developing method was privatized with a neo-liberal approach (Andersen \& Jørgensen, 1995; Majoor, 2008). The local authorities supported the entrepreneurial gain with interventions like transferring the university location, strengthening the area while understanding that the interest from the private sector was lower than expected (Majoor, 2008, 2014). This entrepreneurial development shows a drastic change in the traditional Danish social principles of bottom-up planning (Andersen \& Jørgensen, 1995; Majoor, 2008).

The $\emptyset$ restad district is divided into four different sections. The North section is the most connected to Copenhagen, and some consider it as one of the city's neighborhoods. The detached South section on the edge of the green area is the most populous with housing. Simmons and Krokfors (2015) consider Ørestad's housing as large and architecturally unique. The 8 House is one of the top three most recognized buildings in the district, emphasizing iconism with high quality architecture. 

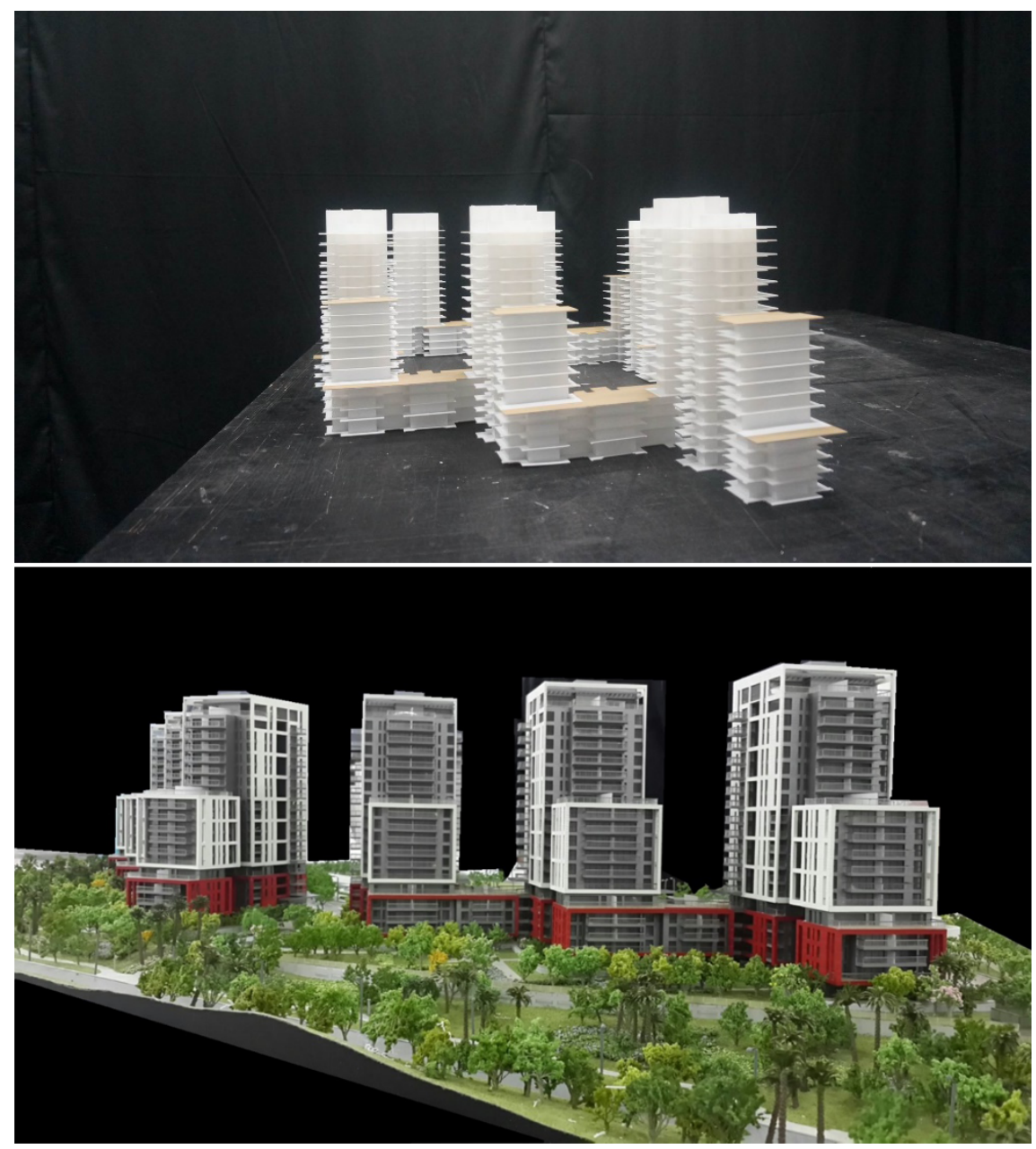

Figure 4. The HH model with and without the 'dress.' Source: K. Braz private collection (2014).

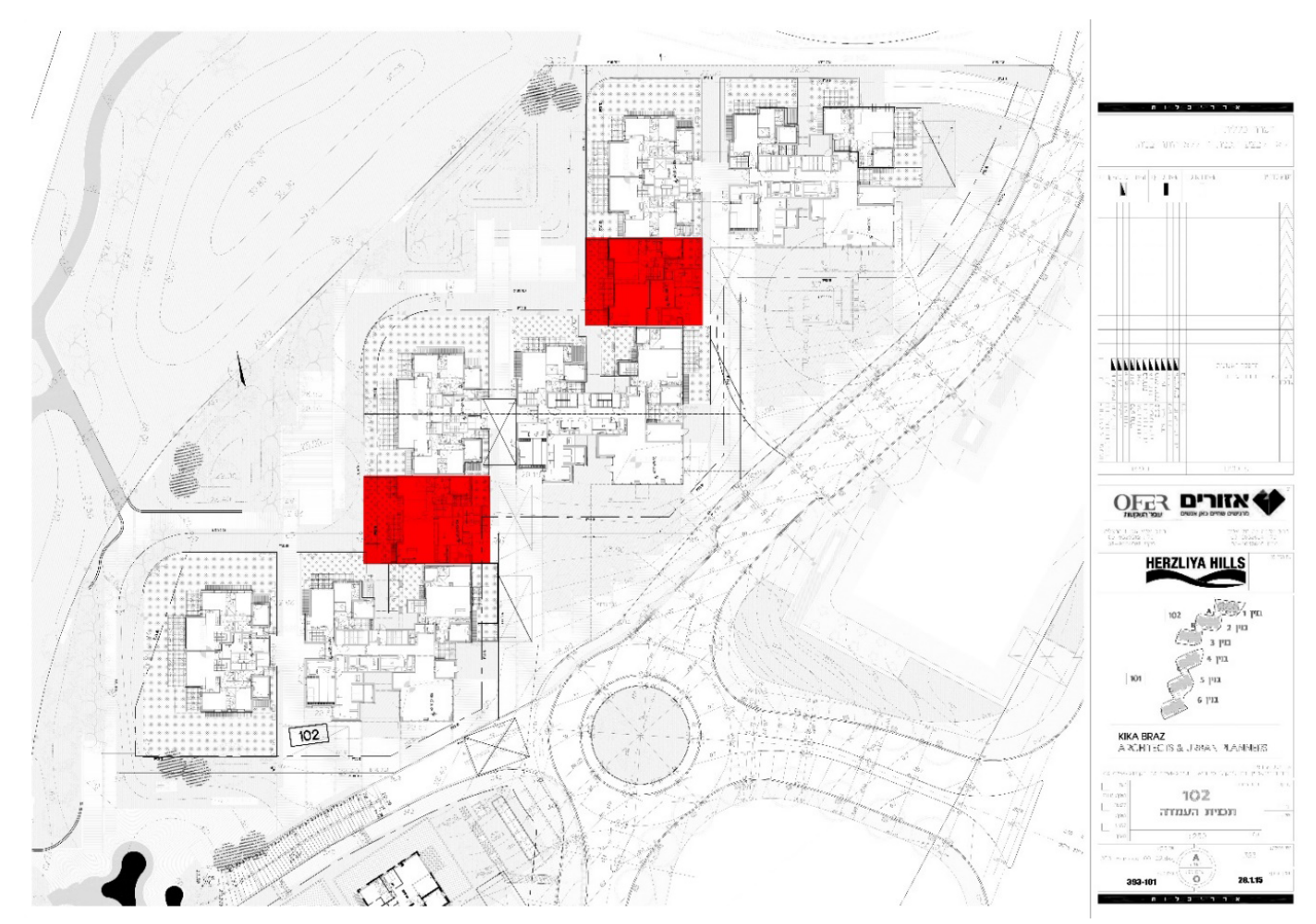

Figure 5. Ground floor plan with the 'boutique buildings' in red. Source: K. Braz private collection (2013). 


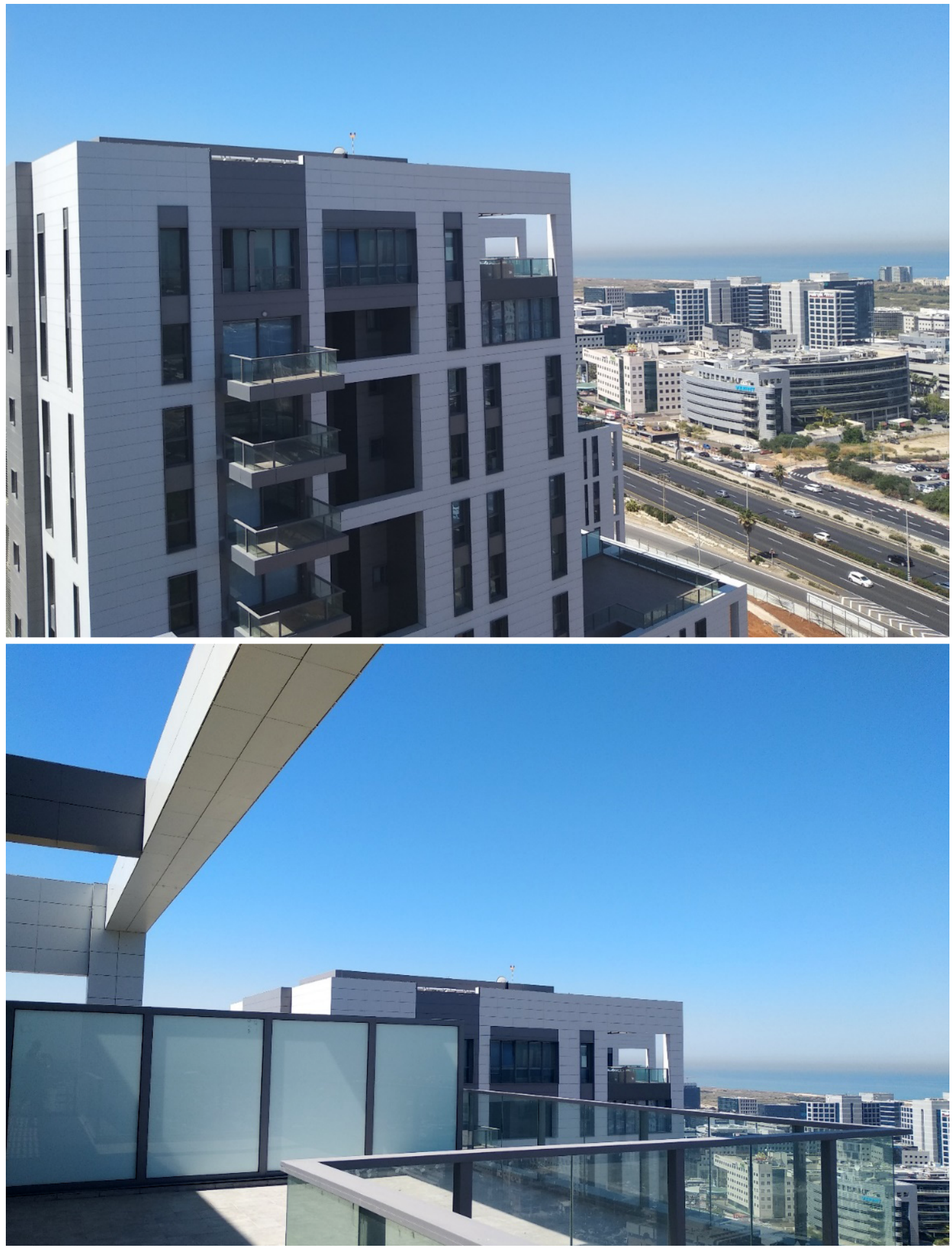

Figure 6. The 'dress' from the penthouse floor. Source: Authors (2019).

Designed by Danish architects from BIG in 2009, 8 House comprises 505 apartments with an overall housing area of 538,195 square feet, siting on 129,167 square feet of commercial space (Stephens, 2009). Rich in apartment types and combining mixed-use spaces for offices and communal services, the LUD is unified via an overarching structural layout in the form of the number 8 , producing a holistic form and organizing element (Figure 8). While embodying a complex mix of open- ings, rotations of apartment façades, and various apartment plans, the LUD's continuous eight-form main-slab 'dresses' the LUD and gives it a holistic image (Figure 9). Apartment schemes do not necessarily follow the continuous outline of the eight-form. And apartment volume does not necessarily fill the entire eight-slab. Left-over spaces function as public space while extended spaces serve as overhead bridges. This architectural act shares similar characteristics to the HH 'dress,' using an overall 


\section{COGITATIO}
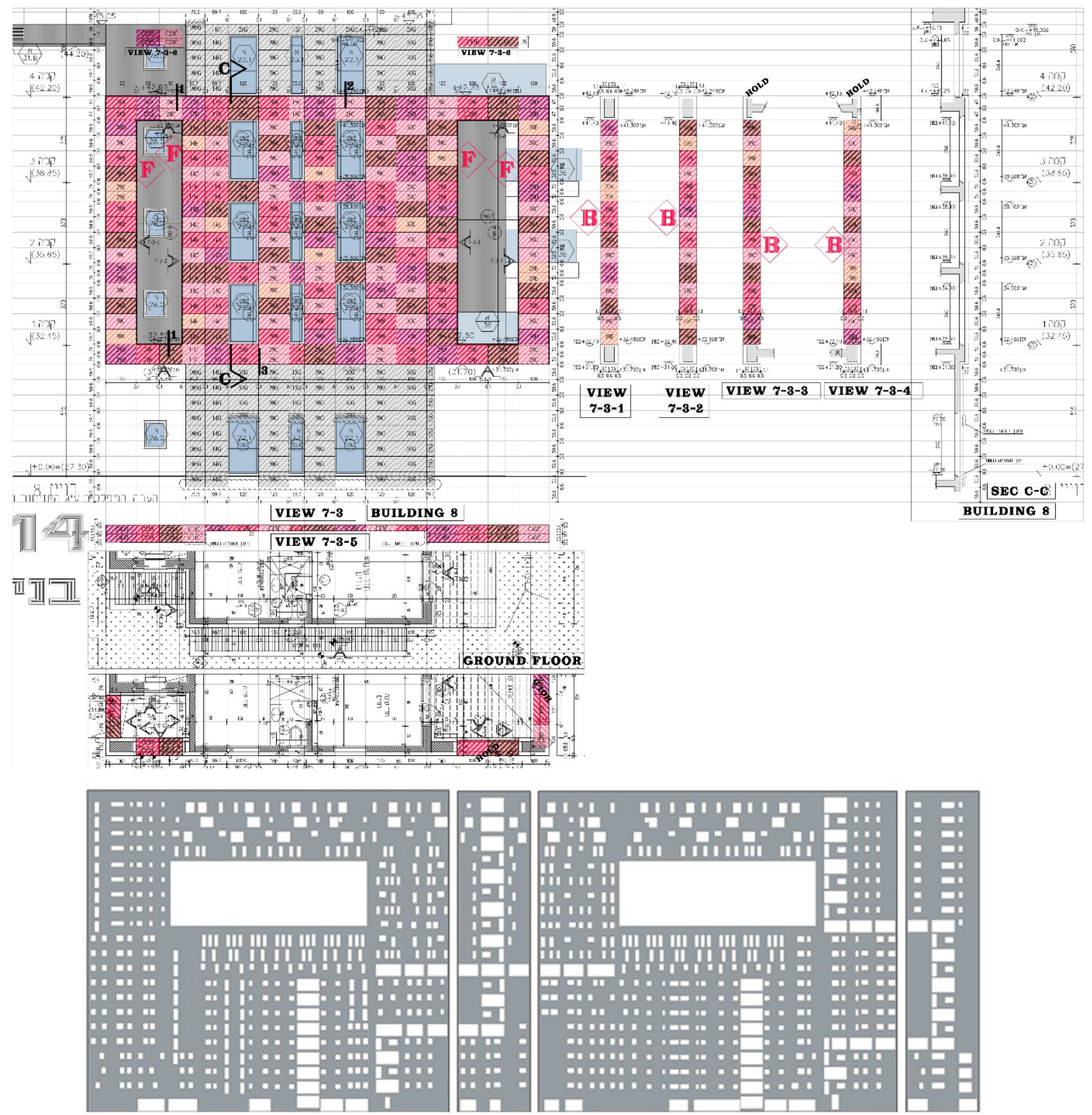

Figure 7. Up: The HH's carefully designed tiles pattern, using grasshopper software. Source: K. Braz private collection (2018). Down: Mirador's 'dress' packaging 'neighborhoods,' a rigorous façade design method. Source: MVRDV (n.d).

packaging element that produces a clear unified form by 'dressing' functional elements of housing like apartments and service areas.

Two additional LUDs which have employed 'dressing' as a design strategy include the Mirador LUD outside Madrid by Dutch firm MVRDV, and VM House in Copenhagen designed by JDS and BIG firms. VM house contains 225 apartments with a gross area of 25,000 square meters, located in the east part of $\varnothing$ restad district, like the 8 House also sufferers from urban fragmentation and zoning. According to BIG's official website, the LUD includes 80 different unique apartment types, most of them multi-leveled. VM façade design is an elaborated, iconic 'dress' that covers this mixture of apartments to create a unifying envelope for the entire LUD. The Mirador, a large block-long building of 156 dwelling units in 22 floors and part the wide social housing program Initiated by the Municipal Council of Madrid, is located at the new residential district of Sanchinarro at the city's North-east. MVRDV design schemes portray the design concept for Mirador as an urban block raised and placed on its side, producing a block sized LUD conceived as one building. Mirador's façade is composed by reassembling the organs of the urban block and packing them together vertically. The façade is therefore a unifying 'dress' that packs the vertical block and holds it together. A transparent veil exposes all the different functions and dwelling types in the LUD, all recognized from the façade by differ- 


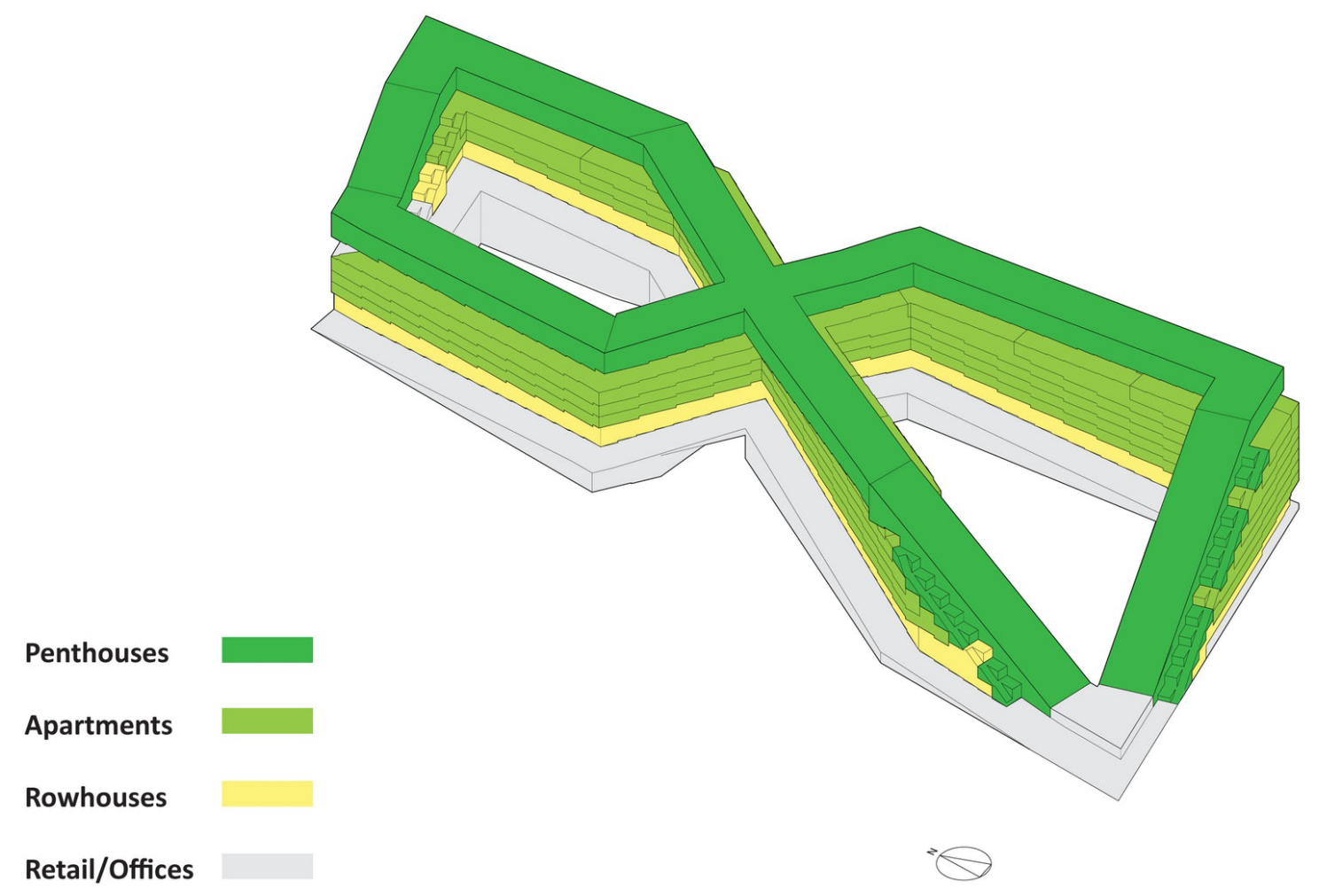

Figure 8. The number 8 layout-the 8 House. Source: Minner (2010).

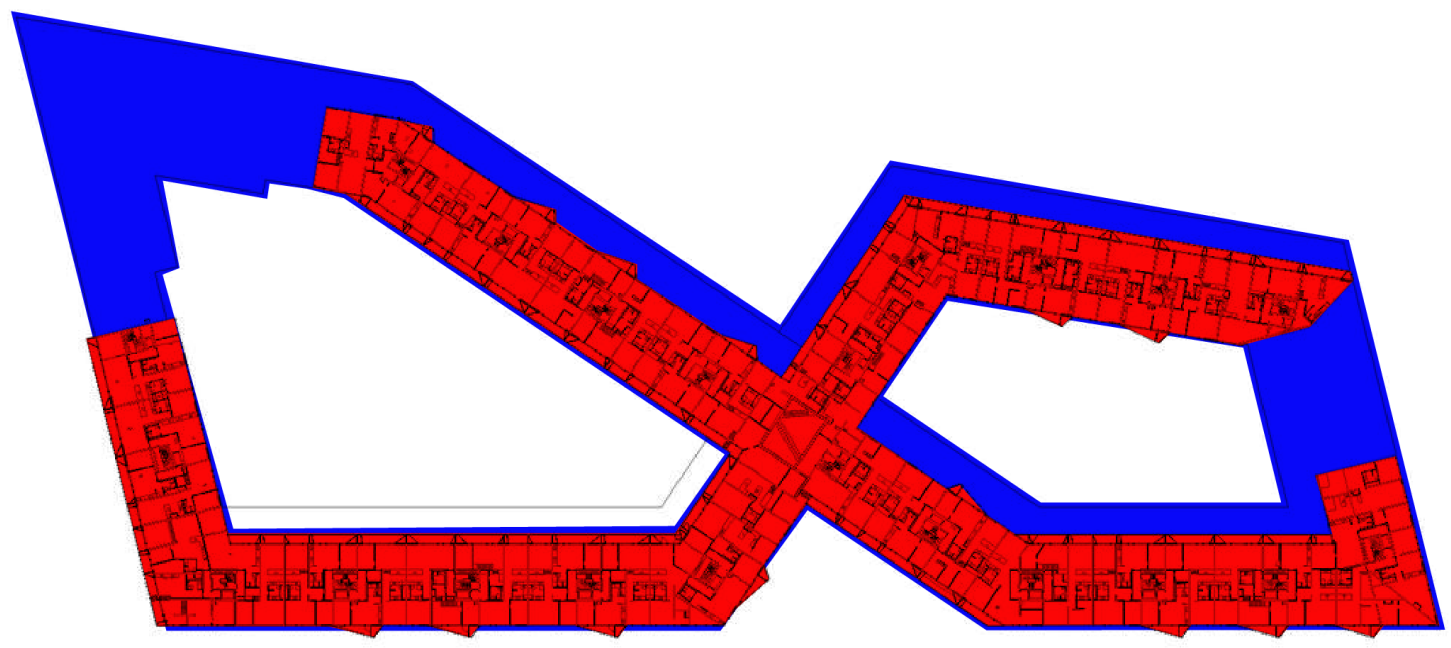

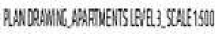

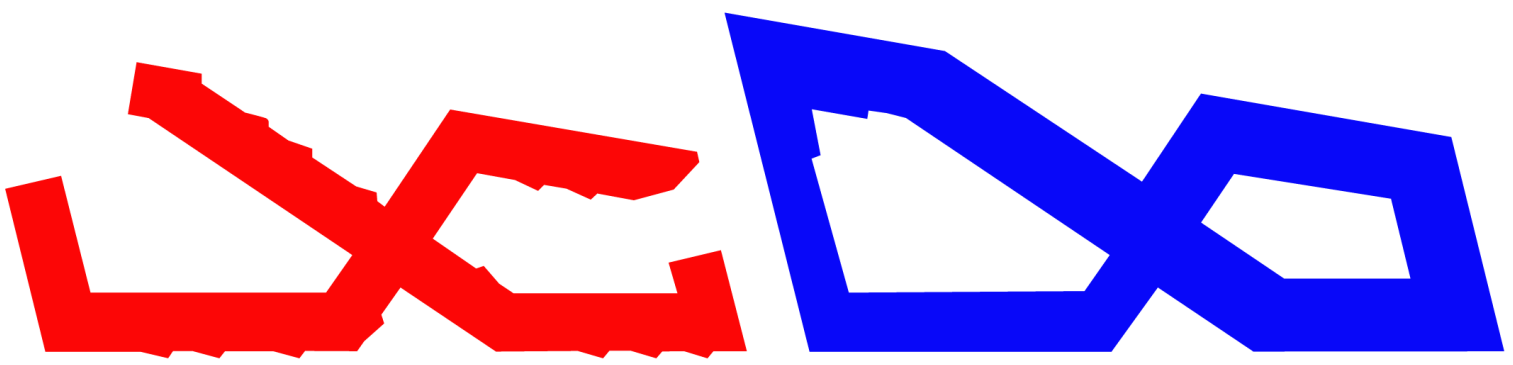

Figure 9. The main slab (blue) packs the apartments all together (red). Source: Adapted from Minner (2010). 
Part-Whole Relationships

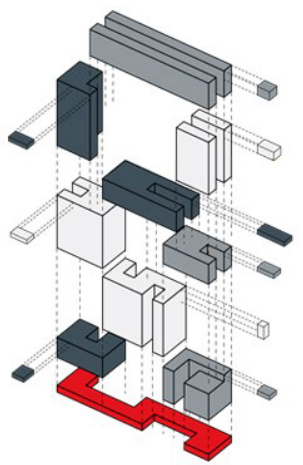

Thresholds + Porosity

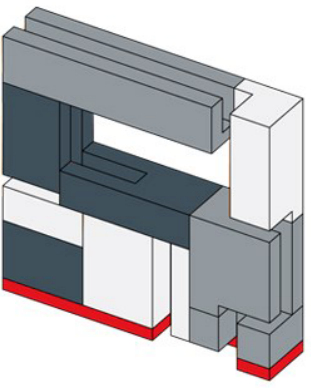

Access + Circulation

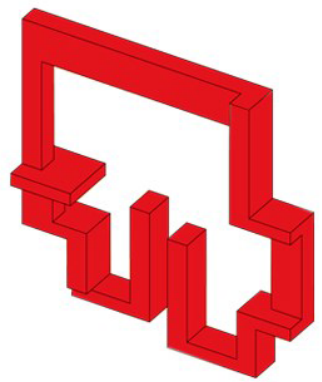

Figure 10. The Mirador urban organs packed together into one LUD. Source: MVRDV (n.d).

ent tile materials and hues (Figure 10). Unlike VM House, Mirador exposes the diversity of spaces in the estate as a design principle, expressed in the façade, employing the 'dress' design method as a unifying structural system of horizontal and vertical movement and shared open spaces, marking it a self-functioning vertical urban block.

\subsection{Rearticulating Urban Form?}

Our case studies are not integrated to the city, following the trajectory of insular development often critiqued for the lack of classic values attributed to urban life (Swyngedouw et al., 2002). The design of 8 House and VM House, both located in Copenhagen's new Ørestad district, arguably revolves around the articulation of an alternative urban grid. Ørestad district faced criticism for the lack of street life and urban variety with the housing building tendency to singularity, creating shallow urban connections with no mutual identity (Simmons \& Krokfors, 2015). The housing area is wholly disconnected from the commercial area by massive boulevards. One of the zoning impacts of the district is the large configuration the developments within-among them Denmark's largest hotel, largest mall, and largest apartment buildings. The VM, in particular, is trapped between the railway infrastructure, creating a dichotomic separation to the West side (Zenari, 2019): "With regard to street liveliness the central area of $\emptyset$ restad, with the construction of Fields...lost its opportunity for real urban quality" (Olsson \& Loerakker, 2013). As can be noticed in the aerial view (Figure 11), the southern section of $\varnothing$ restad contains on its West and South edges several housing de-

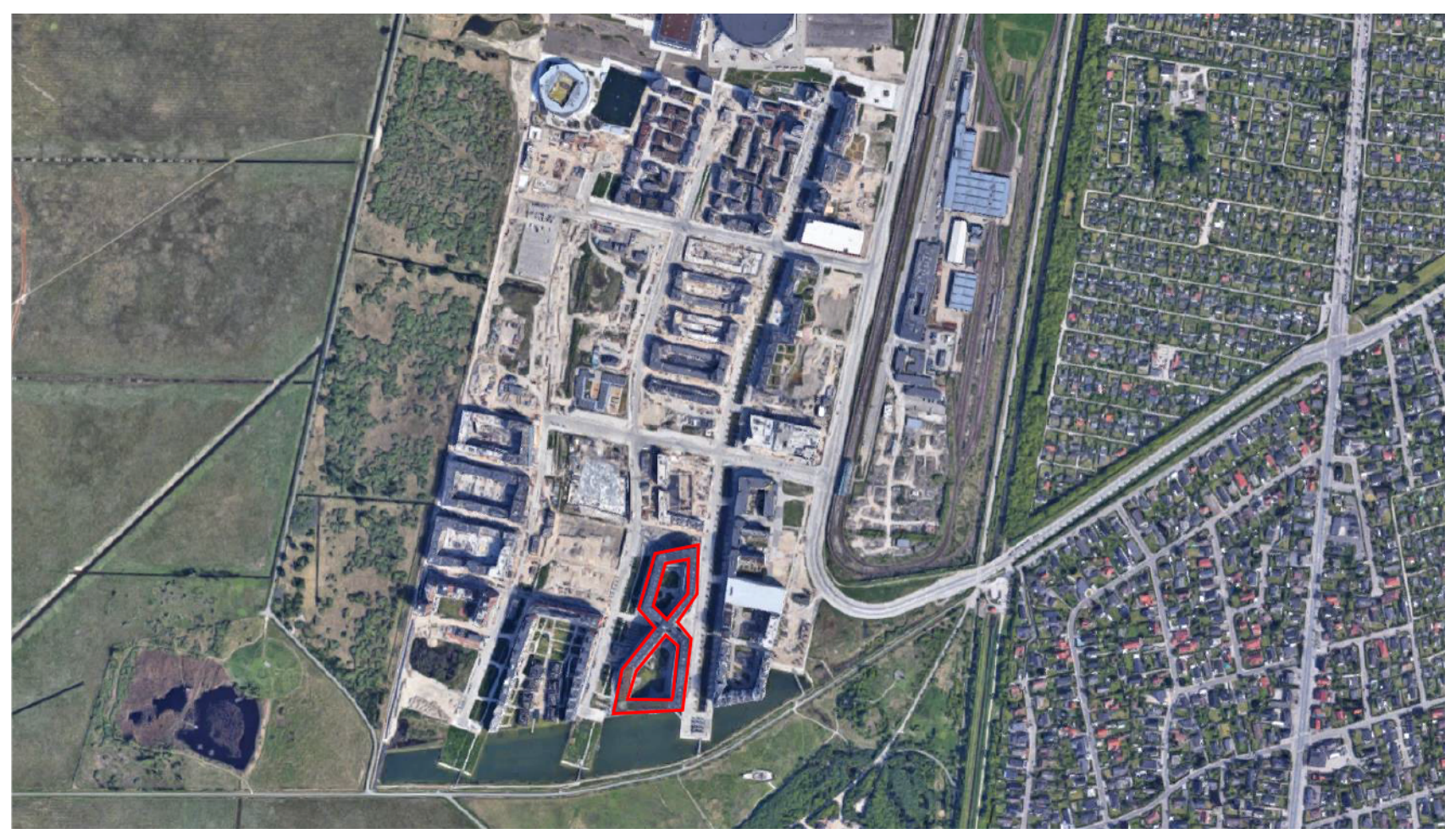

Figure 11. 8 House aerial view on the edge of the south section of $\varnothing$ restad. Source: Authors (2019). 
velopments filling the insula of the grid comprehensively while most of them share a self-centered form. According to Bjarke Ingels, from BIG, the main challenge of this project was dealing with the inherent paradox: While the building architecture requires a coherent form, the urban design seeks for diversity and multiplicity, "in other words, to create a city in a building" (BIG, 2009).

This introverted formation of housing shows an alternate grid that architecture articulated into the housing development. The documentary film The Infinite Happiness follows life at this housing development for 21 days, providing us with a detailed account of both architecture and lived conditions in this celebrated LUD (Bêka \& Lemoine, 2019). The film dedicates each day to one of the building's elements, unpacking the eightshaped LUD by focusing on the mutual relationships between the many elements of the functional operation of the estate and the unified form tying it together. The film describes the main ramp-following the LUD's eight-form comprehensively-that functions as its main open street. Following a resident traveling on a scooter, the film unfolds the diversity of spatial situations the street offers. The street is lined with successive entry balconies to the apartments, separated from the ramp by a low wall and vegetation. Paved with outdoor-use bricks, each of the balconies contains different garden furniture and family chattels, producing an urban street façade. The other side of the ramp-street opens to the inner space of the LUD and overlooks the inner façade. The ramp encounters several covered passages, where atypical floor-plan apartments are located, or transparent public-use spaces. As the continuous ramp circles the outside perimeter of the 8 House, it borders entry balconies and an open view to the LUD surroundings, accessible to all residents. The lower part of the ramp is characterized with more turns, most facing to the inner garden space of the LUD. As the documentary shows, the super-size scale of the development allows it to employ elements of classic urban grid into the large housing development, rearticulating urban form via a unifying design element that does not undermine spatial variety and complexity.
In a similar way, Braz characterized her approach as an integrative typology she terms 'Urban Park Housing Development' that promises to provide the benefits of both precedents using architecture as mediator between developer needs and resident needs. Braz presented her design approach for $\mathrm{HH}$ at the Israeli real estate industry's annual conference in 2014. Under the title Challenges in increasing land rights in high-rise construction (K. Braz, personal communication, November 19, 2014), she located $\mathrm{HH}$ at the intersection of two key architectural precedents: a street in central Barcelona, embodying urban intensity and diversity with a sense of human scale; and Le Corbusier's 'Ville Contemporaine' representing, for her, the entrepreneurial approach of highrise densification with advantages of privacy, light, and ventilation (Figure 12).

In order to meet the limitations of its site, $\mathrm{HH}$ consists of several urban organs along a linear-scheme of disassembled urban elements, with several design principles aiming to produce this new urban typology (Figure 13). The LUD is thus broken down by six pedestrian alleys which divide the built mass in six residential towers placed upon the segmented red slab, to produce a sense of human scale associated with quality-built environments (D. Rozen, personal communication, March 20, 2019). The alleys cross the LUD's main axes, constituting the crossing-element of the new urban grid that connects large-scale office and restaurant developments on its East and the high-tech park across the highway via pedestrian bridge (Figure 14).

Mirador is another new LUD aiming to rearticulate urban form. Its location in Sanchinarro, a new suburb settlement on the edge of the city of Madrid, resulted in the Mirador's antithetic architectural design approach contrasting the conventional housing in an area lacking typological variety and introverted housing development. Mirador is part of a new homogeneous grid of the new district, unlike the rich, variegated and multi-temporal grid of the great city of Madrid. Like the 8 House and $\mathrm{HH}$, Mirador's surroundings suffer from no street vitality. Calvo del Olmo and Garbayo (2017, p. 135) argue that architectural attempts like the Mirador, having a sin-
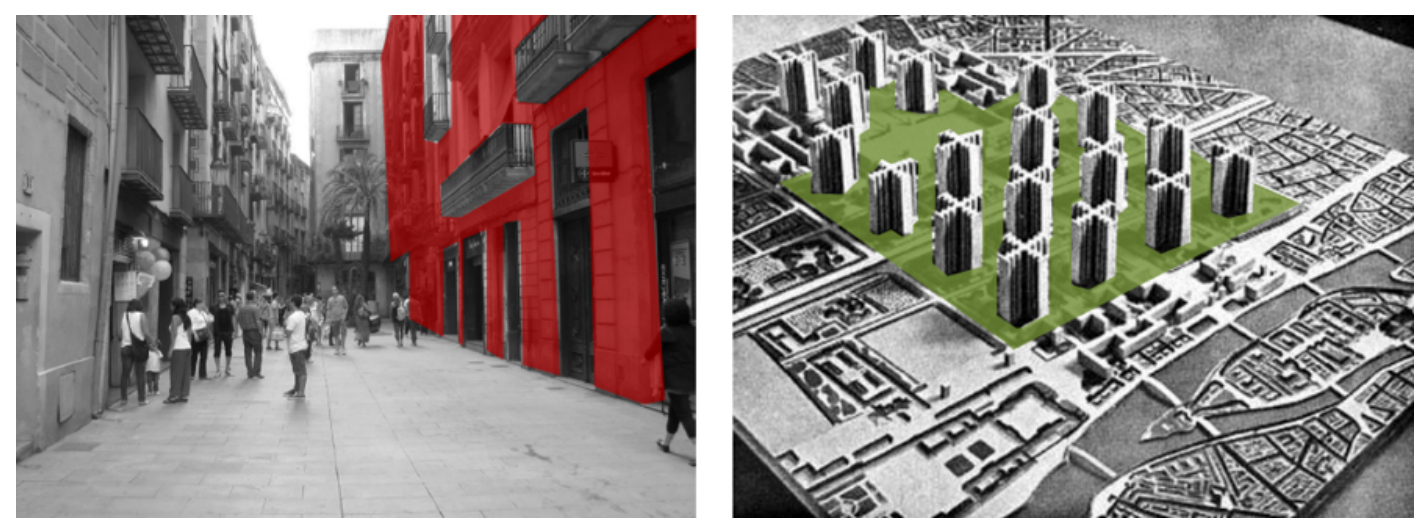

Figure 12. A street in central Barcelona (red) and Le Corbusier 's 'Ville Contemporaine' (green). Source: K. Braz private collection (2014). 


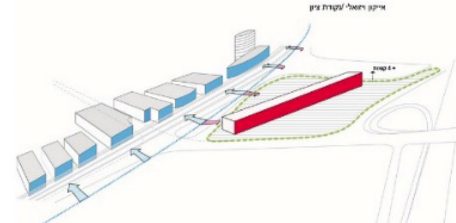

6

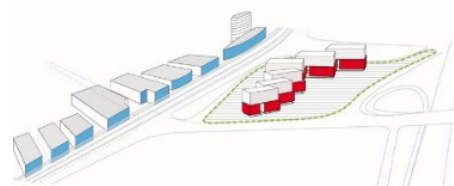

4

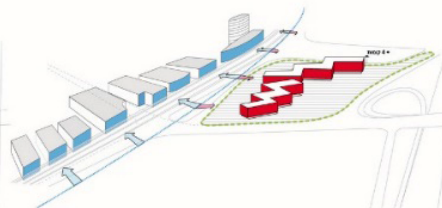

7
2

5

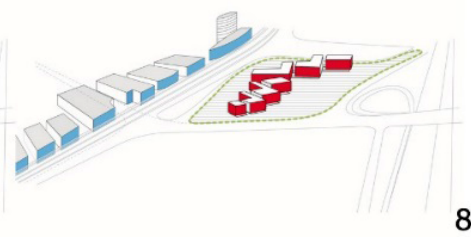

8
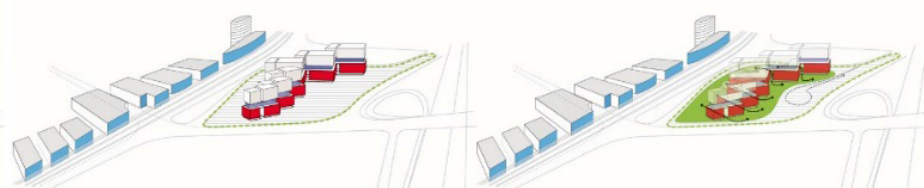

Figure 13. Braz's linear-scheme: reassembling urban elements. Source: K. Braz private collection (2013).

gular feature, is the result of the neoliberal city which is the "non-city." Sanchinarro, planned as part of the 'Programas de Actuación Urbanística,' resulted from filling the shortage in housing by sprawling the city to the suburb under the influence of the neoliberal policy denying urbanity using unsustainable planning approaches of low-density populated settlements (Alonso, Barquero, Vega, \& Pérez, 2014). The starting point for the design process, MVRDV claims, was an 'escape' from the uniformity and claustrophobia of the surrounding neighborhoods filled with six-story blocks (MVRDV, n.d.). In contrast to the grey apartments, the circulation is colored
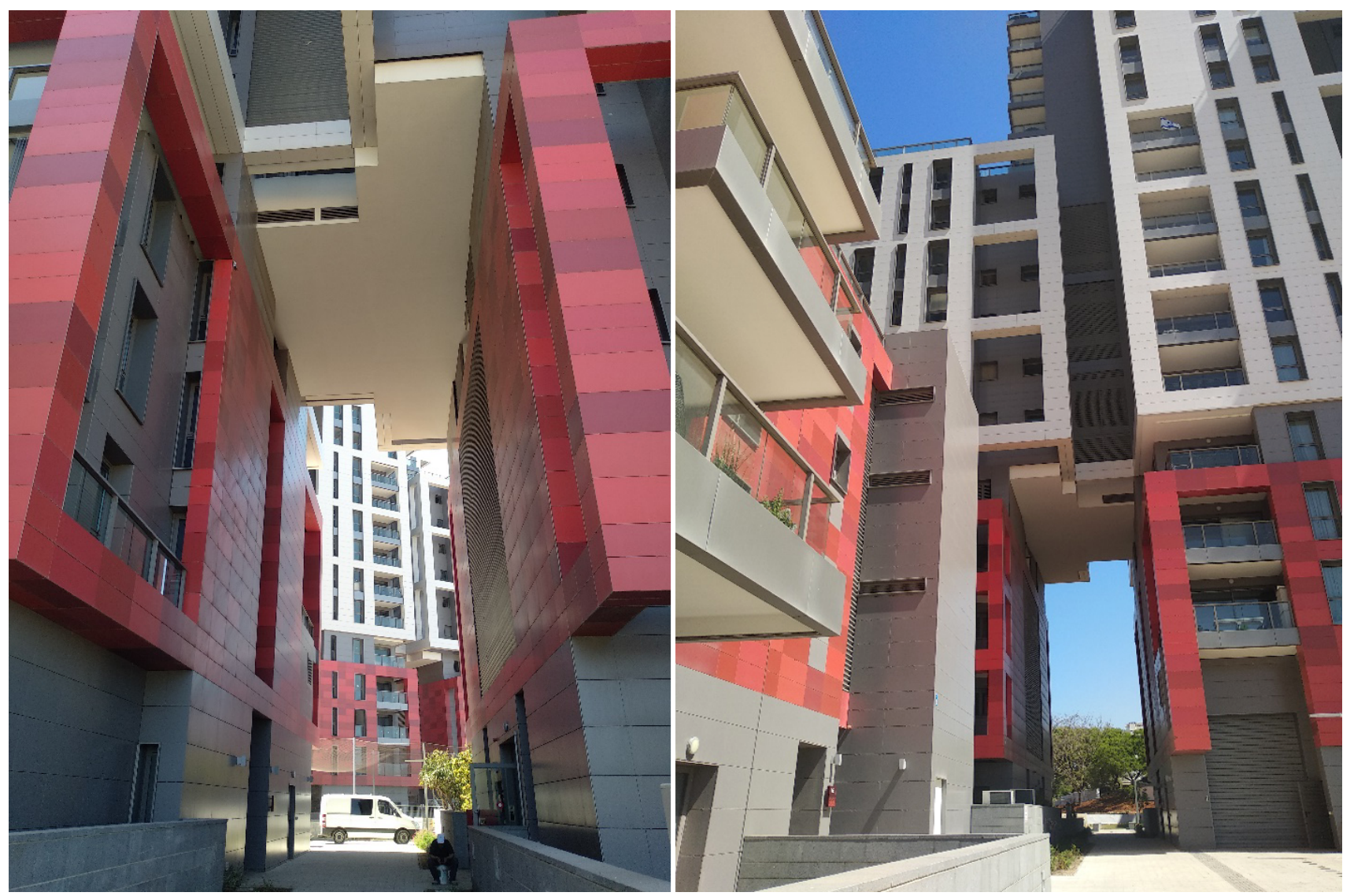

Figure 14. The alleys: crossing the HH's main axes. Source: Authors (2019). 
red. Very distinguished and bold, it contains a variation of different mobility methods that can be seen due to the decision to open the system with no walls facing outside as a vertical open street. The red-colored elements of the circulation system agglomerate the compendium of dwelling types in the LUD and structures them like small suburbs. Vertical sequences of stairs, halls, platforms, and streets, thus create a vertical neighborhood (MVRDV, n.d.). One of the iconic pictures of Mirador is a perspective from one of the 'corridors' designed facing the green-blue view, supplementary to the circulations in red (Figure 15). The corridor, almost three floors high and open to the sky, defines the apartments' entrances crossing stairs with balconies overlooking this 'street.' The vertical LUD boasts an open terrace, 40 meters above the ground. The semi-public sky-plaza overlooks the city, puncturing this large housing development and marking it as organ of the city.

\subsection{The Neoliberal Estate}

The welfare state initiated public housing and had a crucial part in the role of determining the mixture of the population. This responsibility reverted to entrepreneurial companies, minimizing state involvement in decisionmaking. Star-architect Patrik Schumacher eschews the modern idea of community-creation to point to the private developer who sells a platform of community forma- tion through a bargaining process between customers. With this perspective, Schumacher identifies a new role assigned to architects in creating new communities, as they mediate between social-collective interests and economic ones (Schumacher, 2002).

HH marketing agent Cohen identifies the LUD's 42 different apartment types in six towers and smaller 'boutique' buildings as one of its powerful marketing characteristics, offering buyers the future ability to extendor shrink-their residential environment. $\mathrm{HH}$ therefore produces a diversified community by appealing to three main categories of buyers: young families who can only afford a small apartment and want the ability to expand and buy a bigger apartment without leaving the neighborhood; families with older children who may later want to move to a small apartment in the same neighborhood; and elderly couples who want to move from their spacious villas to a smaller urban apartment (I. Cohen, personal communication, May 14, 2019).

While $\mathrm{HH}$ provides the different types of apartments sporadically in the development, Mirador packs every different type as a 'neighborhood' showed at the façade and glued together into a superblock. This architectural approach was declaring the story of the building as hosting different dwelling units, producing a mixed community. The apartments are packed tighter leaving no space, the in-between of these neighborhoods contains the public space open to air, light, and view.

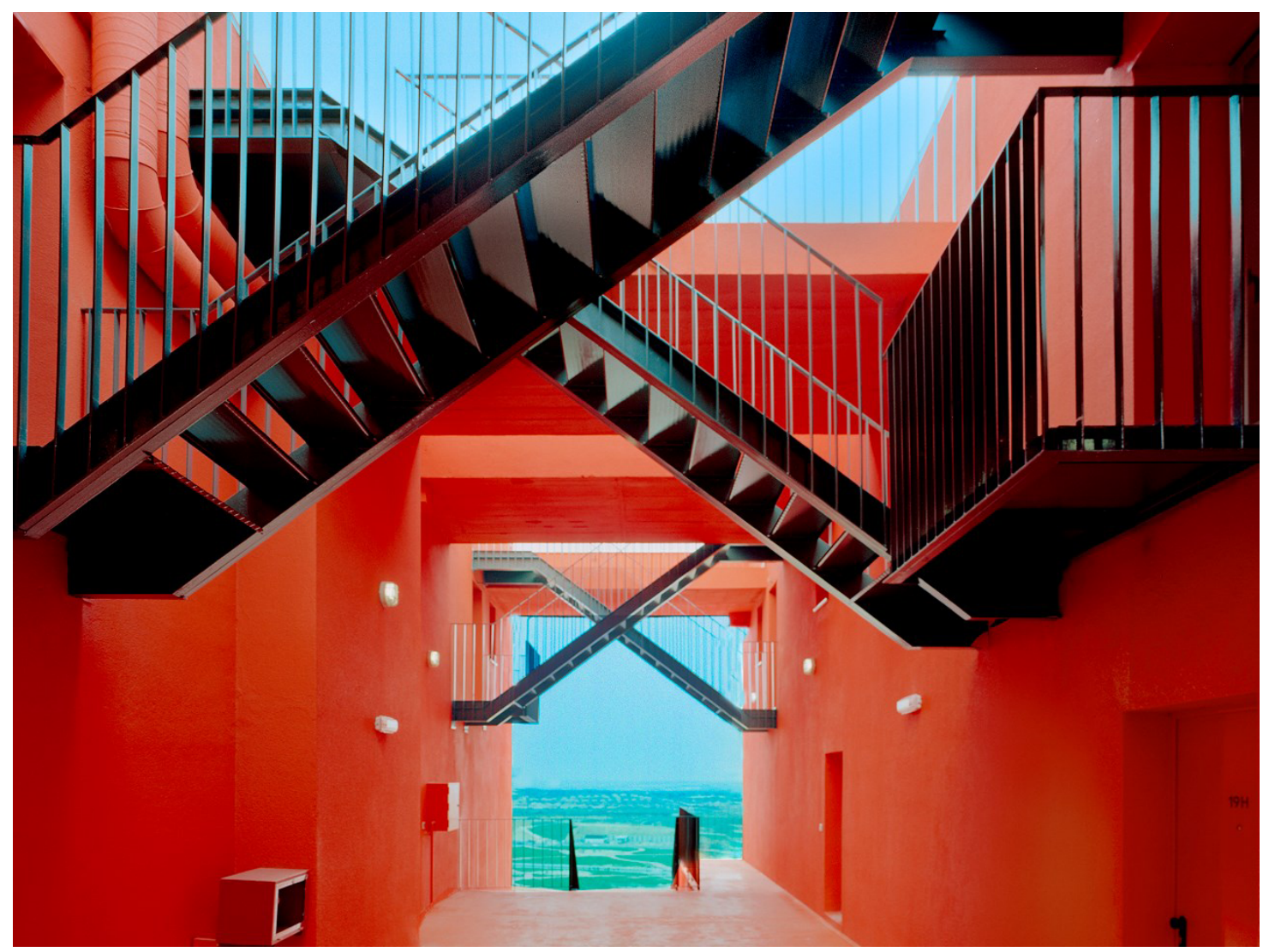

Figure 15. The Mirador corridor as a 'street.' Source: MVRDV (n.d.). 
Likewise, 8 House includes a multi-generation community, as shown in The Infinite Happiness. The film follows three generations of one family living in three separate apartments. The family's choice to purchase apartments at this development and live in proximity is explained by their past experiences of communal residence, with positive memories shared by parents and children. Family members indicate that since 8 House is commercial housing, one can choose privacy but still enjoy community life in this estate. Residents testify that they do not lock apartment doors, revealing a sense of security reasoned by the small community, where everybody knows eachother's faces and unexpected guests can be identified quickly (Bêka \& Lemoine, 2019).

This market based, neoliberal community therefore presents itself as choice-based collective home, whose terms of membership are nonetheless determined by the financial capacity thus producing market-controlled social diversity. "8 House is a three-dimensional neighborhood rather than an architectural object," says Bjarke Ingels (Minner, 2010). Compared to a regular neighborhood, with most community life limited to the ground floor, the 8 House enjoys social interactions in all floor levels. The row of 150 houses stretching from the bottom to the top provide the building with complex multi-dimensional community engagement (Minner, 2010). Fostering social interactions, the focal point of the project is the vertex of the number 8 , the position of the intersection of both courtyards connects all the communal facilities: common room, guest apartments, lounges, cinema, and roof terrace. The most centralized location in the building, it also provides vertical connections and East-West connection paths to the neighboring buildings in the area. In an article titled "BIG's 8 House succeeds where the Smithsons' "streets in the sky' failed," Bjarke Ingels (Mairs, 2016) extols the ambitious design principle of encouraging social interaction in mass housing. First proposed by Le Corbusier and later discussed by Team X members and especially the Smithsons in the British context, housing architecture attempted to design encouraging social interactions between dwellers.
Ingels claims that after this brutalist approach failed in Britain, it is now achieved in Copenhagen at 8 House due to its three-dimensional interactions, while the Smithson focused only on the ground floor (Mairs, 2016).

While the material of VM's 'dress' shares similarities to the commercial and cultural building's façade in the center of the district, the architects (JDS and BIG) interpreted community life through diversification. The variegation related to the experimental architectural figuration of the housing building in Ørestad, aimed to compensate for the homogeny's morphology, making it strategically attractive (Losasso \& D'Ambrosio, 2012). In a 2005 magazine article overviewing the architects and the project, BIG is presented as a young architect firm, with no LUD experience, that inventively mixes typology of forms and programs (Stephens, 2009). Although the project is creative and has a bold look, the developer indicates that the project met budget limitations, thus suggesting that good variant architecture is independent from big economic resources (Stephens, 2009). With this limitation, the VM house came to be an affordable residential project with sustainable social configurations. Its apartment diversity opened the development to a wider range of residents resulting from the different qualities and costs (Losasso \& D'Ambrosio, 2012). The architects present VM as a take on Le Corbusier's 'Unité d'habitation,' claiming to improve the long successive corridors, making them open to light. The open view from the two edges making the corridors "attractive social space" (BIG \& VM Houses, n.d.). Another similarity to Le Corbusier's innovative mass housing project is the packaging morphology. The VM presents a rigorous Tetris-packaging method of the variant apartment offering a diverse community (Figure 16), a progressive version of the L-shaped in cross-section. The architects' allusion to Le Corbusier's famous project indicates their communal approach-and role-in shaping the new community while taking into account entrepreneurial developing limitations and requirements.

Creating neoliberal housing estates that attempt to produce the architectural values aspired by social hous-
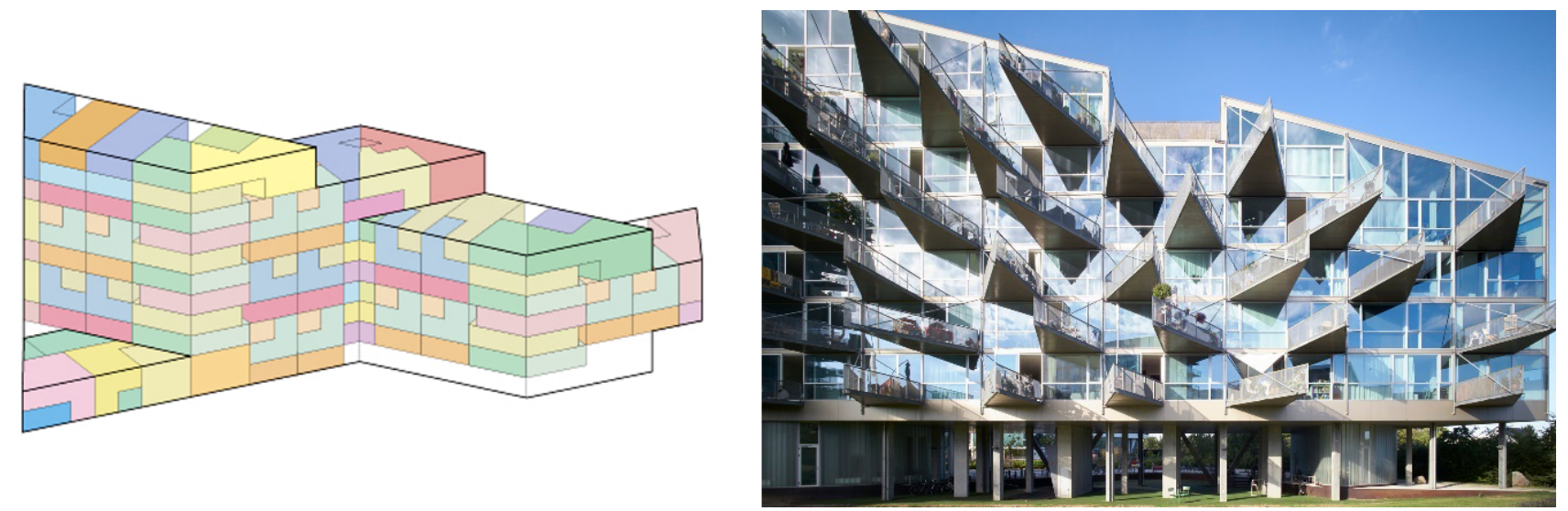

Figure 16. The VM Tetris-packaging method of the variant apartment versus the 'dress' covering the verity. Sources: BIG and VM Houses (n.d) and BIG + JDS (2008). 
ing estates of the post-war period, the architects of $\mathrm{HH}$, VM House, 8 House and Mirador attempt to employ the opportunity given to them by LUD developers to extend architectural design from the envelope to the private and public spaces of the LUD housing as housing estates.

\section{Conclusion}

This article expounds on the crucial role of architectural design of housing LUDs in the current neoliberal context. While mass housing emerged as a social, spatial, and political challenge following the Industrial Revolution, contemporary housing production is dominated by entrepreneurs' interest in using LUD housing as an investment channel. Neoliberal market housing has nonetheless presented us with the paradox by which the market's promise of variety is unfulfilled, producing replicated, repetitive built environments like many of the mass housing it aimed to replace.

But as LUDs exhaust the city as vehicle for capital growth towards less-desirable sites, developers assign renewed roles for design in early development processes even in housing. Seeking new ways to re-engage with social action in large housing developments, LUD architects employ architectural methods to confer LUDs with the variety and multiple choice promise of market development, unpacking the neoliberal paradox. LUD architects intentionally attempt to deal with the site's desirability problem using design. In so doing, they contribute to the project's entrepreneurial capital gain. As shown, architecture takes a leading role in marketing considerations foregrounding the design process. New architectural interpretations of introvert urban typology propose alternate grids of streets with varying scales, alleys, and squares. 'Dressing' the LUD with unifying and iconic architectural elements contributes to the goals of functional variety and the marketing needs of urban landmarks. Isolated and self-contained, LUDs constitute independent urban elements. The role assigned to architectural design in our case studies sets the fundamental terms of the large-scale built environment for the 'great number' and presents the capacity of for-profit housing LUDs to foster neoliberal communities premised upon the LUD platform.

Comparing the case studies discussed in this article along the three analytical themes we identify-(a) the value of architecture; (b) re-articulating urban form; and (c) the neoliberal estate-we exposed the actual decision-making and design-thinking involved in introducing architecture into large housing developments.

The role of architecture in producing value and image via envelope design is manifest in the four cases. Mirador's 'dress' - based on a 'quilt façade' packaging every typology separately-tells a story of diversity with its large-scale appearance, high-floor plaza, and using coloring between apartment types. The 8 House, 'dressed' in the illustrative image of the number 8 , reveals a detailed façade implying the richness of typologies. HH's 'dress,' with most of its 42 different apartment types less noticeable, reveals only the differential between the six separate high buildings (white) to the successive ground floor (red) connecting while even hiding the boutique small buildings. The VM House proposes a dichotomic relationship between its façade appearance and its extraordinary architectural diversity. Made with glass and steel, the VM 'dress' outlines the form of the letters $V$ and $M$ and boasts a large number of pointed triangular balconies. This singular 'dress' conceals the 80 different types of apartments packed in this LUD.

All four case studies exemplify dis-integration with the city and lack of classical urban values. Their architectural design presents an introverted formation of dwelling that creates a new articulation of the missing urban grid inherent in the singular housing development. BIG architects harness this situation in Ørestad housing buildings, combining two different approaches: coherence (a building) and diversity (city), making a multidimensional grid. $\mathrm{HH}$ and Mirador embed urban organs in the singular form: successive ground floor with crossing alleys cutting the buildings in the $\mathrm{HH}$; 'sky plaza' and multi-floor alleys open to the view in Mirador. This re-articulation takes the classic urban organ and reinterprets it in the form of LUD.

The neoliberal era entrusts entrepreneurial companies with determining the population mixture, in the absence of the welfare state. Architects take this opportunity to design large-scale housing developments and further develop architectural design approaches and tools of post-war housing estate architecture. $\mathrm{HH}$, 8 House, VM, and Mirador offer diversified apartment types. $\mathrm{HH}$ provides the ability to change apartments attuned to changing family situations. 8 House, a threedimensional neighborhood, embeds communal facilities for a wide range of ages. VM uses a progressive method of 'Unité d'habitation' in a rigorous Tetris packaging, while Mirador ties different 'neighborhoods' to one superblock, using it as a design method.

\section{Acknowledgments}

Research for this article was supported in part with an Azrieli Fellowship awarded by the Azrieli Foundation.

\section{Conflict of Interests}

The authors declare no conflict of interests.

\section{References}

Aalbers, M. (2016). The financialization of housing: A political economy approach. London and New York, NY: Taylor \& Francis.

Alonso, E. C., Barquero, M. C. E., Vega, M. D., \& Perez, R. G. (2014). Back to the centre: In search of new residential infrastructures for public use in the consolidated city. In R. Cavallo, S. Komossa, N. Marzot, M. 
Berghauser Pont, \& J. Kuijper (Eds.), Back to the centre (pp. 832-838). Amsterdam: IOS Press.

Allweil, Y. (2017). Homeland: Zionism as housing regime, 1860-2011. London: Routledge.

Amsterdam, Z., Delft, F. B., \& Eburon, U. (2017). Disconnected innovations. New urbanity in large-scale development projects: Zuidas Amsterdam, Ørestad Copenhagen and Forum Barcelona. Delft: Uitgeverij Eburon.

Andersen, H. T., \& Jørgensen, J. (1995). Copenhagen. Cities, 12(1), 13-22.

Bauer, C. (1934). Modern housing. Boston, MA: Houghton Mifflin Harcourt.

Bêka, I. (Producer), \& Lemoine, L. (Director). (2019). The Infinite Happiness [Motion picture]. France and Denmark: Bêka \& Partners.

Bjarke Ingels Group. (Producer). (2009). 8H: The 8-House. [Motion picture]. Denmark: Bjarke Ingels Group.

Bjarke Ingels Group, \& VM Houses. (n.d.). Projects. Bjarke Ingels Group. Retrieved from https://big.dk/ \#projects-vm

Bjarke Ingels Group + JDS (2008). VM houses/BIG + JDS. Arch Daily. Retrieved from https://www.archdaily. com/970/vm-houses-plot-big-jds

Boyer, M. C. (2017). Not quite architecture: Writing around Alison and Peter Smithson. Cambridge, MA: MIT Press.

Brand, R., \& Shalom, O. (2014). Patterns of contemporary living. Montreal: Sternthal Books.

Brenner, N., Marcuse, P., \& Mayer, M. (2011). Cities for people, not for profit: Critical urban theory and the right to the city. Abingdon: Routledge.

Calvo del Olmo, J. M., \& Garbayo, J. D. (2017). The postmodern city: A critique-The application of neoliberal strategies in Madrid metropolitan area. In G. Sağlamer, M. Aksoy, \& F. Erkök (Eds.), Rethinking, reinterpreting and restructuring composite cities (pp. 121-137). Newcastle upon Tyne: Cambridge Scholars Publishing.

Cupers, K. (2014). The social project: Housing postwar France. Minneapolis, MN: University of Minnesota Press.

Efrat, Z. (2019). The object of Zionism: The architecture of Israel. Leipzig: Spector Books.

Eleb, M. (2000). An alternative to functionalist universalism: Écochard, Candilis, and Atbat-Afrique. In S. W. Goldhagen \& Réjean Legault (Eds.), Anxious modernisms: Experimentation in postwar architectural culture (pp. 55-73). Montreal: Canadian Centre For Architecture.

Engels, F. (1993). The condition of the working class in England. New York, NY: Oxford University Press. (Original work published 1872)

Gualini, E., \& Majoor, S. (2007). Innovative practices in large urban development projects: Conflicting frames in the quest for "New Urbanity." Planning Theory \& Practice, 8(3), 297-318. https://doi.org/10. 1080/14649350701514637
Handel, D. (2018). Not Beverly or Hills but surprisingly pleasantly as an office complex. Haaretz. Retrieved from https://www.haaretz.co.il/gallery/ architecture/.premium-1.6545829

Harvey, D. (2003a). Paris, capital of modernity. Hove: Psychology Press.

Harvey, D. (2003b). The right to the city. International Journal of Urban and Regional Research, 27(4), 939941.

Harvey, D. (2004). The 'new' imperialism: Accumulation by dispossession. Socialist Register, 40, 63-87.

Harvey, D. (2010). Social justice and the city. Athens, GA: University of Georgia Press.

Harvey, D. (2012). Rebel cities: From the right to the city to the urban revolution. New York, NY: Verso Books.

Jameson, F. (1991). Postmodernism, or, the cultural logic of late capitalism. New York, NY: Verso Books.

Le Corbusier. (2008). Toward an architecture. London: Frances Lincoln.

Lefebvre, H. (1991). The production of space. Oxford: Wiley-Blackwell.

Losasso, M., \& D'Ambrosio, V. (2012). Eco-districts and social housing in Northern Europe. TECHNE-Journal of Technology for Architecture and Environment, 2012(4), 44-52.

Mairs, J. (2016). BIG's 8 House succeeds where the Smithsons' "streets in the sky" failed, says Bjarke Ingels. Dezeen. Retrieved from https://www.dezeen. com/2016/02/03/big-8-house-robin-hood-gardenssmithsons-streets-in-the-sky-failed-says-bjarkeingels

Majoor, S. J. H. (2008). Progressive planning ideals in a neo-liberal context, the case of $\varnothing$ restad Copenhagen. International Planning Studies, 13(2), 101-117.

Majoor, S. J. H. (2014). Ørestad: Copenhagen's radical new town project in transition. Planning Theory \& Practice, 15(3), 432-438. https://doi.org/10.1080/ 14649357.2014.935610

Marcuse, P., \& Madden, D. (2016). In defense of housing: The politics of crisis. New York, NY: Verso Books.

Martin, R., Moore, J., \& Schindler, S. (2015). The art of inequality: Architecture, housing, and real estate-A provisional report. New York, NY: The Temple Hoyne Buell Center for the Study of American Architecture.

Mattsson, H. (2015). Where the motorways meet: Architecture and corporatism in Sweden 1968. In M. Swenarton, T. Avermaete, \& D. van den Heuvel (Eds.), Architecture and the welfare state (pp. 155-176). Abingdon: Routledge.

Mazzucato, M. (2018). The value of everything: Making and taking in the global economy. London: Hachette UK.

McLeod, M. (1989). Architecture and politics in the Reagan era: From postmodernism to deconstructivism. Assemblage, 1989(8), 22-59.

Minner, K. (2010). 8 House/BIG. Arch Daily. Retrieved from https://www.archdaily.com/83307/8-housebig 
Mitchell, D. (2003). The right to the city: Social justice and the fight for public space. Abingdon: Taylor \& Francis.

Mota, N., \& Allweil, Y. (2019). The value of housing. Footprint, 13(1), 1-10.

MVRDV. (n.d.). Mirador. MVRDV. Retrieved from https:// www.mvrdv.nl/projects/135/mirador

Novy, A., Redak, V., Jäger, J., \& Hamedinger, A. (2001). The end of red Vienna: Recent ruptures and continuities in urban governance. European Urban and Regional Studies, 8(2), 131-143.

Olsson, L., \& Loerakker, J. (2013). The story behind failure: Copenhagen's failed business district $\emptyset$ restad. Failed Architecture. Retrieved from http:// www.failedarchitecture.com/thestory-behind-thefailure-copenhagens-businessdistrict-orestad

Parvu, S. (2010). Grands ensembles en situation: Journal de bord de quatre chantiers [Grands ensambles in context: Account of four modernist housing projects]. Geneva: Métis Presses.

Rosenberg, A. (2010). 8 House: BIG win for BIG. Arch Daily. Retrieved from https://www.archdaily.com/ 73947/8-house-big-win-for-big

Salet, J. (2008). Rethinking urban projects: Experiences in Europe. Urban Studies, 45(11), 2343-2363.

Schumacher, P. (2002). Autopoeisis of a residential community. In B. Steele \& +RAMTV (Eds.), Negotiate my boundary: Mass-customisation and responsive environments. London: Architectural Association Publications.

Self, J. (2014). Real estates: Life without debt. London: Bedford Press.

Simmons, R., \& Krokfors, K. (2015). Scandinavian housing design since the mid 1990s: Selected lessons from practice. Built Environment, 41(2), 305-324.

Smithson, A. M., Smithson, P., van den Heuvel, D., Risselada, M., \& Colomina, B. (2004). Alison and Peter Smithson: From the house of the future to a house of today. Rotterdam: 010 Publishers.

Spencer, D. (2016). The architecture of neoliberalism: How contemporary architecture became an instrument of control and compliance. London: Bloomsbury Academic.

Stephens, S. (2009). BIG Bjarke Ingels Group: A young
Danish architectural firm is living up to its acronym with bold projects home and abroad. Architectural Record, 197(12), 35.

Stoiljkovi, B., \& Jovanovi, G. (2015). Individualization concept in housing architecture. Architecture and Civil Engineering, 13(3), 207-218. https://doi.org/10. 2298/FUACE1503207S

Swenarton, M., Avermaete, T., \& Van Den Heuvel, D. (2014). Architecture and the welfare state. Abingdon: Routledge.

Swyngedouw, E., Moulaert, F., \& Rodriguez, A. (2002). Neoliberal urbanization in Europe: Large-scale urban development projects and the new urban policy. Antipode, 34(3), 542-577.

van den Heuvel, D. (2014). The open society and its experiments: The case of the Netherlands and Piet Blom. In M. Swenarton, T. Avermaete, \& D. van den Heuvel (Eds.), Architecture and the welfare state (pp. 133-154). Abingdon: Routledge.

van den Heuvel, D. (2015). The open society and its experiments: The case of the Netherlands and Piet Blom. In M. Swenarton, T. Avermaete, \& D. van den Heuvel (Eds.), Architecture and the welfare state (pp. 133-154). Abingdon: Routledge.

van den Heuvel, D., \& Risselada, M. (2005). Team 10: In search of a utopia of the present, 1953-1981. Rotterdam: NAi Publishers.

Vestergaard, H., \& Scanlon, K. (2014). Social housing in Denmark. In K. Scanlon, C. Whitehead, \& M. F. Arrigoitia (Eds.), Social housing in Europe (pp. 77-89). Hoboken, NJ: Wiley-Blackwell.

Zaera-Polo, A. (2008). The politics of the envelope. Log, 2008(13/14), 193-207.

Zaera-Polo, A. (2017). Well into the 21st century: The architectures of post-capitalism? El Croquis, 187, 252-287.

Zenari, L. B. (2019). The relation between buildings and public spaces in the context of sustainable compact cities. Understanding the impacts on human behavior: Cases of Ørestad and Hammarby Sjöstad (Unpublished Masters dissertation). KTH Royal Institute of Technology, School of Architecture and the Built Environment, Stockholm, Sweden.

\section{About the Authors}

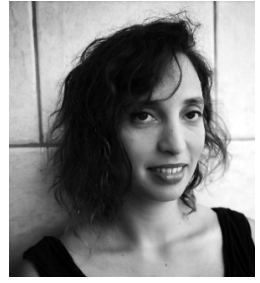

Merryan Majerowitz is an Architect and a Master's Student in the Faculty of Architecture and Town Planning at the Technion, Israel. Her research examines replication of residential environments in neoliberal Israel, in which housing is primarily a commodity in a market economy. The research aims to ask in-depth questions regarding architectural ethics and illuminate and analyze the design processes currently taking place in Israel. Through the research, Merryan hopes to contribute to the development of theoretical as well as practical knowledge, to enrich the public debate together with an effective change in planning systems. 


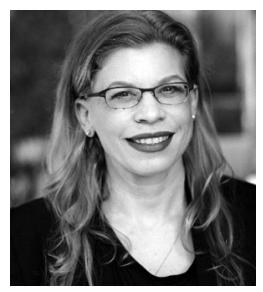

Yael Allweil (PhD) is an Architect and Assistant Professor in the Faculty of Architecture and Town Planning at the Technion, Israel, where she heads the Housing Architecture, History and Theory research group. She completed her PhD in Architecture History at UC Berkeley exploring the history of Israel-Palestine as a history of the gain and loss of citizen housing. Her research was published in the monograph Homeland: Zionism as Housing Regime 1860-2011 (Routledge, 2017) and several journal articles in Urban Studies, Footprint, Architecture Beyond Europe, City, TDSR and IJIA. During 2019-2020, Yael will be on leave at the Institute for Advanced Studies (IIAS) in Jerusalem as chair of the research group Re-Theorizing Housing as Architecture (with Gaia Caramellino and Susanne Schindler). Yael's work involves academic research and activism in the context of the Israeli housing social movement. 